УдК 635.63:631.527

03.00.00 Биологические науки

\section{ИКОНОГРАФИЯ ПШЕНИЦЫ}

Цаценко Людмила Владимировна

д-р. биол. наук, профессор, кафедра генетики, селекции и семеноводства

ID 2120-6510

Кубанский государственный аграрный

Университет имени И.Т.Трубилина, Россия,

Краснодар 350044, Калинина 13

lvt-lemna@yandex.ru

Представлено исследование истории агрокультуры, ее распространения и использование путем анализа изображения, иконографии. В качестве объекта исследования взят образ пшеницы, древней культуры мира среди сельскохозяйственных растений. По пришествии многих лет иллюстративный ряд приобретает совершенно иное значение, а именно становиться самостоятельным ресурсом информации. В анализ вошли образы пшеницы в живописи, скульптуре, мозаике, гобеленах, фресках, ботанической иллюстрации, марках, фарфоре и научных рисунках. В работе предпринята попытка провести анализ образов пшеницы в произведениях искусства с целью поиска видового разнообразия, направлений селекционно-генетических исследований, а также представить морфологические характеристики культуры. Метод анализа - метод визуальных заметок или скетчей, состоящий в сравнении и поиска информации по образу. Приводится анализ по признакам: высокорослые пшеницы, многоцветковые формы пшеницы, неполегание, толщина соломины. Проведенный визуальный анализ образов пшеницы в произведениях искусства методом скетчей позволил выявить видовое разнообразие культуры по колосу, увидеть стародавние формы, которые возделывались в мире до «зеленой революции». В анализ вошли произведения искусства с 14 по 21 века, мастеров живописи Италии, Германии, России, Нидерландов, Франции, США и др.

Ключевые слова: ПШЕНИЦА, МЕТОД СКЕТЧЕЙ, ВИЗУАЛЬНЫЙ АНАЛИЗ, МНОГОЦВЕТКОВЫЕ ФОРМЫ, КОРОТКОСТЕБЕЛЬНЫЕ СОРТА, ИКОНОГРАФИЯ ОБРАЗА

Doi: 10.21515/1990-4665-133-021
UDC 635.63:631.527

Biology

\section{ICONOGRAPHY OF WHEAT}

Tsatsenko Luidmila Vladimirovna

Dr.Sci.Biol., professor,

Chair of genetic, plant breeding and seeds

ID 2120-6510

Kuban State Agrarian University named after

I.T.Trubilin, Krasnodar, Russia

lvt-lemna@yandex.ru

The study of agronomy plants history, its distribution and use through image analysis and iconography have been presented. As an object of study, the image of wheat has been taken as the ancient culture of the world among agricultural plants. After many years, the illustrative series takes on a completely different meaning, namely, it becomes an independent resource of information. The analysis includes images of wheat in painting, sculpture, mosaic, tapestries, murals, botanical illustrations, stamps, porcelain and scientific drawings. In the work, we have made an attempt to analyze the images of wheat in the works of art in order to search for species diversity, directions of selection and genetic research, and also to present the morphological characteristics of culture. The method of analysis is a method of visual notes or sketches, which consists in comparing and searching information by image. The analysis is carried out on grounds: tall wheat, multiflorous forms of wheat, nonspreading, thickness of straw. The visual analysis of the images of wheat in works of art by the method of sketches made it possible to reveal the species diversity of culture along the ear, to see the ancient forms that were cultivated in the world before the "green revolution". The analysis included works of art from the 14th to the 21st century, the masters of painting in Italy, Germany, Russia, the Netherlands, France, the United States, and others

Keywords: WHEAT, METHOD OF SKETCHES, VISUAL ANALYSIS, MULTICULAR FORMS, SHORT-SIZED SORTS, ICONOGRAPHY OF IMAGE

Исследование по образу растений или иконографии, иконическому изображению, становится актуальным направлением работ по изучению 
происхождения сельскохозяйственных растений, их интродукции и археогенетики. Ранее научную иллюстрацию рассматривали как средство, помогающее понять суть биологических явлений, как идентификационный критерий при распознавании биологических форм жизни. По пришествии многих лет иллюстративный ряд приобретать совершенно иное значение, а именно становиться самостоятельным ресурсом информации. В этой связи мы обратились к ботанической иконографии - изображениям растений в живописи, скульптуре, мозаике, гобеленах, фресках, ботанической иллюстрации, марках, фарфоре а также научных рисунках. Этот термин появился сравнительно недавно, впервые его успешно применил Джулиан Дженик в генетико-селекционных исследованиях по истории интродукции ряда культур с Американского континента в Европу [10,19,20].

В живописи XVII-XVIII вв. интенсивно развивался ботаникодекоративный стиль, характеризующийся научной объективностью. Создатели живописных полотен во многом следовали принципам флористического рисунка, интерес к которому возрос настолько, что выделился в особую сюжетную разновидность графики. Благодаря тщательной передачи облика растений, картины вполне могли выступать в качестве иллюстраций к ботаническим атласам. Так, образы растений, нашедшие отражение в различных произведениях искусства, могут служить документальным материалом по истории истории агрокультур, археогенетики и истории селекции $[8,11]$.

В нашей работе предпринята попытка провести анализ образов пшеницы в произведениях искусства, с целью поиска видового разнообразия, направлениям селекционно-генетических исследований, a также морфологическим характеристикам культуры.

Для анализа использовалась база данных «Иконография пшеницы», насчитывающая 235 образа, информационный ресурс «Завод изображений», университета Пердью в городе Уэст-Лафейетт, штат 
Индиана, www.hort.purdue.edu/newcrop/iconography, фотографии картин и образов пшеницы лоджий Рафаэля были сделаны в Государственном Эрмитаже и Русском музее, г.Санкт-Петербург 2017 году [12,13,16,17].

Метод анализа - метод визуальных заметок или скетчей, состоящий в сравнении и поиска информации по образу [14, 15].

Пшеница принадлежит к трем важнейшим сельскохозяйственным мировым культурам наряду с кукурузой и рисом. Эволюция пшеницы представляет собой образец примера аллополиплоидии. У пшеницы выделяют несколько видов: однозернянку $(2 \mathrm{n}=2 \mathrm{x}=14)$ и ее используют преимущественно как крупяную культурную; макаронную или твердую пшеницы $(2 \mathrm{n}=4 \mathrm{x}=28)$, к этой группе относится и полба $(2 \mathrm{n}=4 \mathrm{x}=28)$ и мягкая пшеница $(2 \mathrm{n}=6 \mathrm{x}=42)$. Гексаплоидная пшеница (Triticum aestivum L., состав генома AABBDD) возникла благодаря межвидовой гибридизации между тетраплоидной полбой двузернянки (T.turgidum ssp.diccocum, AABB) и эгилопсом Тауша (Aegilops tauschii syn.Ae.squarrosa, DD) около 8000-12000 лет тому назад. Тетраплоидная пшеница (AАBВ) возникла в результате гибридизации полбыоднозернянки (T.monococcum, AA) и донора носителя В-генома, вероятно Ae.speltoides. Диплоидные и тетраплоидные формы пшеницы принадлежат к старейшим культурным растениям, и происходят из Передней Азии [1, $2,6,9]$.

В древние времена посевы пшеницы представляли собой смесь различных ее видов: однозернянки (T.monococcum L.), беотикум (T.boeoticum Bioss), урарту (T.urartu Thum Ex Gandil); тетраплоидных полбы (T.diccocum Schubl.), туранской (T.turanicum Jakubz), твердой (T.durum Desf.) и гексаплоидной мягкой пшеницы.(T.aestivum L.)

В эпоху перехода от неолита к меди (V тысячелетие до н.э.) египтяне уже выращивали ячмень и пшеницу-двузернянку (эммер), которые служили основой питания вплоть до греко-римского периода. В библии 
пшеница упоминается один раз, а полба-двузернянка - три раза (рисунок 1).

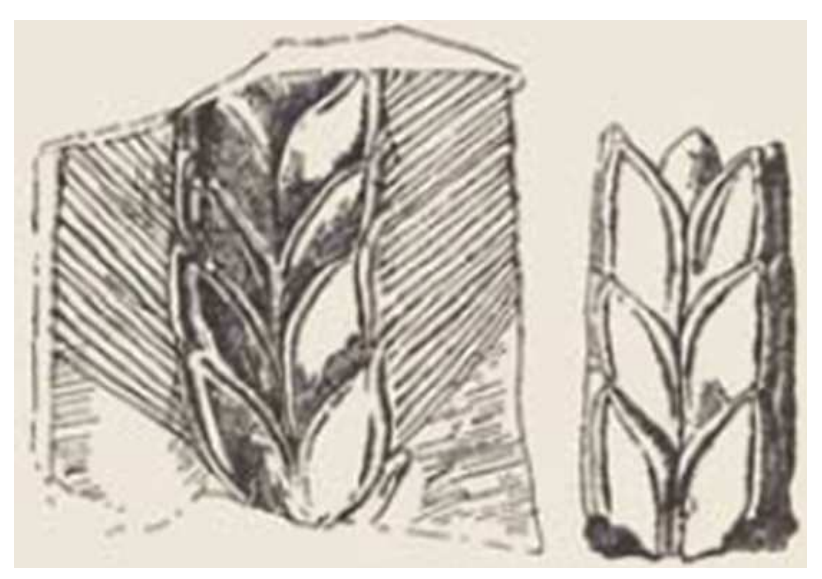

Рисунок 1 -Древнее изображение пшеницы, 5 лет до н.э.

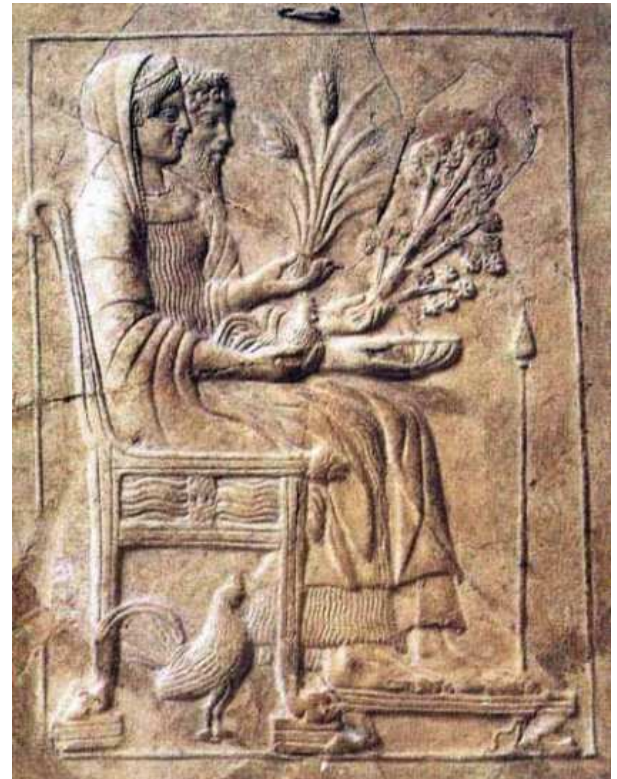

Рисунок 2 - Аид и КораПерсефона на троне. Аид держит в руках цветы сельдерея, а Персефона - колосья пшеницы. Глиняный сосуд с рельефом из Локри Эпизефирии. Начало V в. до н.э.
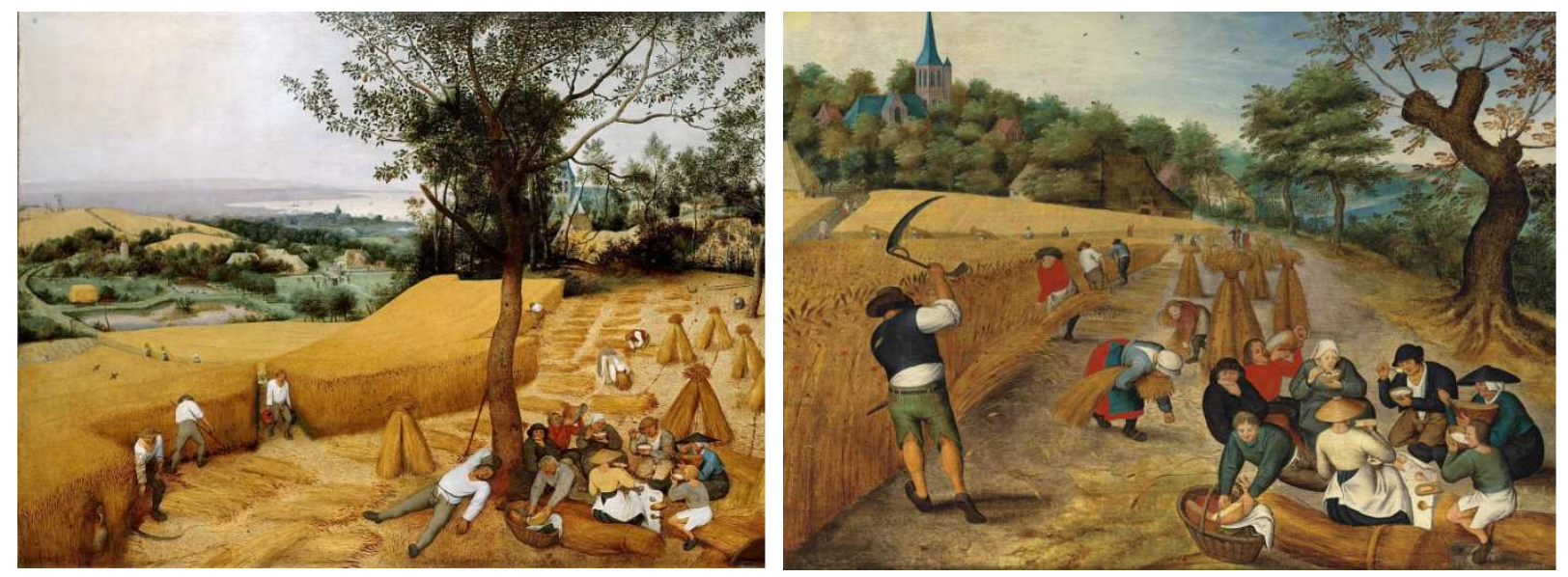

Рисунок 3 - Сенокос, Питер Старший Брейгель. 1556 г.(слева)

Лето, Питер Брейгель, Младший 1623 г.(справа) 
С картинами Питера Брейгеля Старшего, Питера Брейгеля млашего, немецкого художника, графика, гравера эпохи ренессанса Ганса Себальда Бехама, (рисунки 3-4), миниатюрой Саймона Бенинга «Август». 1540 г. связана история механизации уборки хлебов. Как пишет С.Ф.Коваль (2010), уборка серпом со связыванием в снопы практиковалась почти всю историю земледелия [3]. На этом этапе человек мало внимания обращал на полегание злаков - уборка велась с помощью серпа и это ей не мешало. Длинная, не огрубевшая солома, рассматривалась даже как положительное свойство пшеничного растения. Солома шла на корм скоту, на подстилку, ей покрывали крыши домов, топили печи. Появление товарного зернового хозяйства потребовало более производительных методов уборки. Возникли конные жатки, а потом и логрейки. Скашивать полегший хлеб жаткой можно только навстречу наклону стеблей. Маленькой конной жаткой легко маневрировать по полю и скашивать полегший хлеб в одном направлении. На этом этапе полегающие сорта устраивали земледельца.

Высокорослые пшеницы нашли отражение в картинах: крупнейшего мастера офорта эпохи маньеризма лотарингского гравера и рисовальщика Жака Калло. В 1610-1611 годах он создал серию «Месяцы», где изображены высокорослые пшеницы и их уборка серпом; французского художника Никола Пуссен, стоявший у истоков живописи классицизма. Им была создана серия пейзажей «Четыре времени года» с библейскими сценами, символизирующими историю мира и человечества: «Весна», «Лето», «Осень», «Зима». В теме «Лето» изображены высокорослые пшеницы и в картинах немецкого художника Ганса Себальда Бехама (рисунок 5).

Затем пшеница заняла громадные площади в прериях Северной Америки, Аргентины, в степях Украины и на Кубани. Зерно здесь выращивали главным образом на продажу. Земледельцы были 
заинтересованы убрать урожай как можно быстрее и с минимальным количеством рабочих. Из этой потребности и родился комбайн, объединивший в одной машине уже существующие жатку, молотилку и простейшую веялку.

Однако возникла другая проблема. Производительный, но громоздкий комбайн имел свои недостатки, как пишет С.Ф. Коваль (2010) - при уборке полегшего хлеба он давал громадные потери урожая. Никакие ухищрения конструкторов не могли решить эту проблему. С ростом урожая посевы зерновых культур все чаще полегают. Решать эту задачу пришлось селекционерам, которые перешли к созданию сортов с прочной неполегающей соломиной. Ранее созданный задел селекционного материала полегающих форм «был выброшен и затраченные на его создание усилия пропали даром» [4].

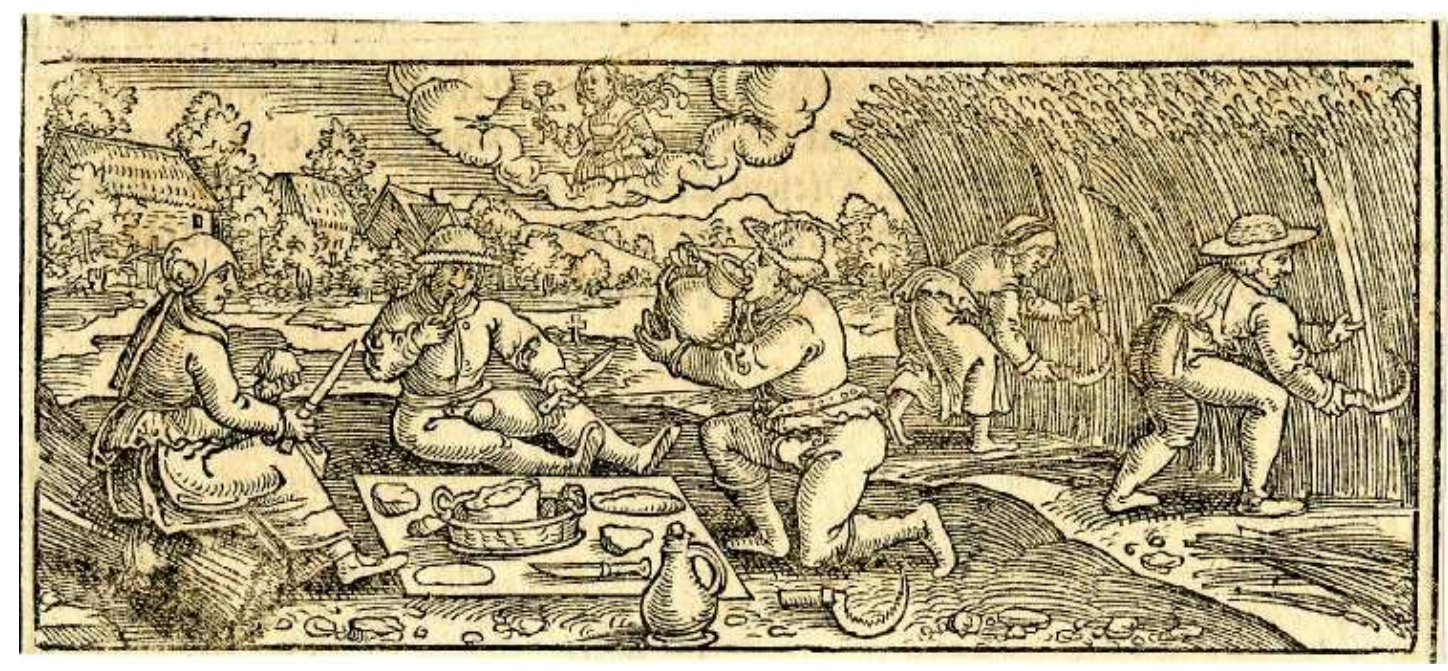

Рисунок 4 - Уборка хлеба, Ганс Себальд Бехам, 1500 г.

К этому моменту не только расширялись посевные площади, росла и культура земледелия, широко стало практиковаться применение удобрений. Открытие минеральных удобрений знаменовало начало целой эпохи, а относительно дешевое их промышленное производство произвело переворот в сельском хозяйстве. С этого момента низкое естественное 
плодородие того или иного поля перестало играть главенствующую роль главное была бы обеспеченность минеральными удобрения. К середине XX в. сельское хозяйство получило огромное количество минеральных удобрений, но ранее созданные сорта не могли эффективно трансформировать их в урожай.

Таким образом, произошел переход к селекции короткостебельных сортов зерновых злаков, получивший название «зеленая революция». «Отцом зеленой революции» был американский селекционер, лауреат Нобелевской премии Норман Борлауг. Под его руководством в 1944 г. проходила мексиканская программа по пшенице и позже эти работы были продолжены в Индии по короткостебельным сортам риса. В малых фарфоровых формах - фрагмент настольного украшения Императорского фарфорового завода (рисунок 6) отражены два типа пшеницы: высокорослые и низкорослые, которые использовались как источник генов короткостебельности в дальнейших селекционных программах с местными сортами пшеницы.
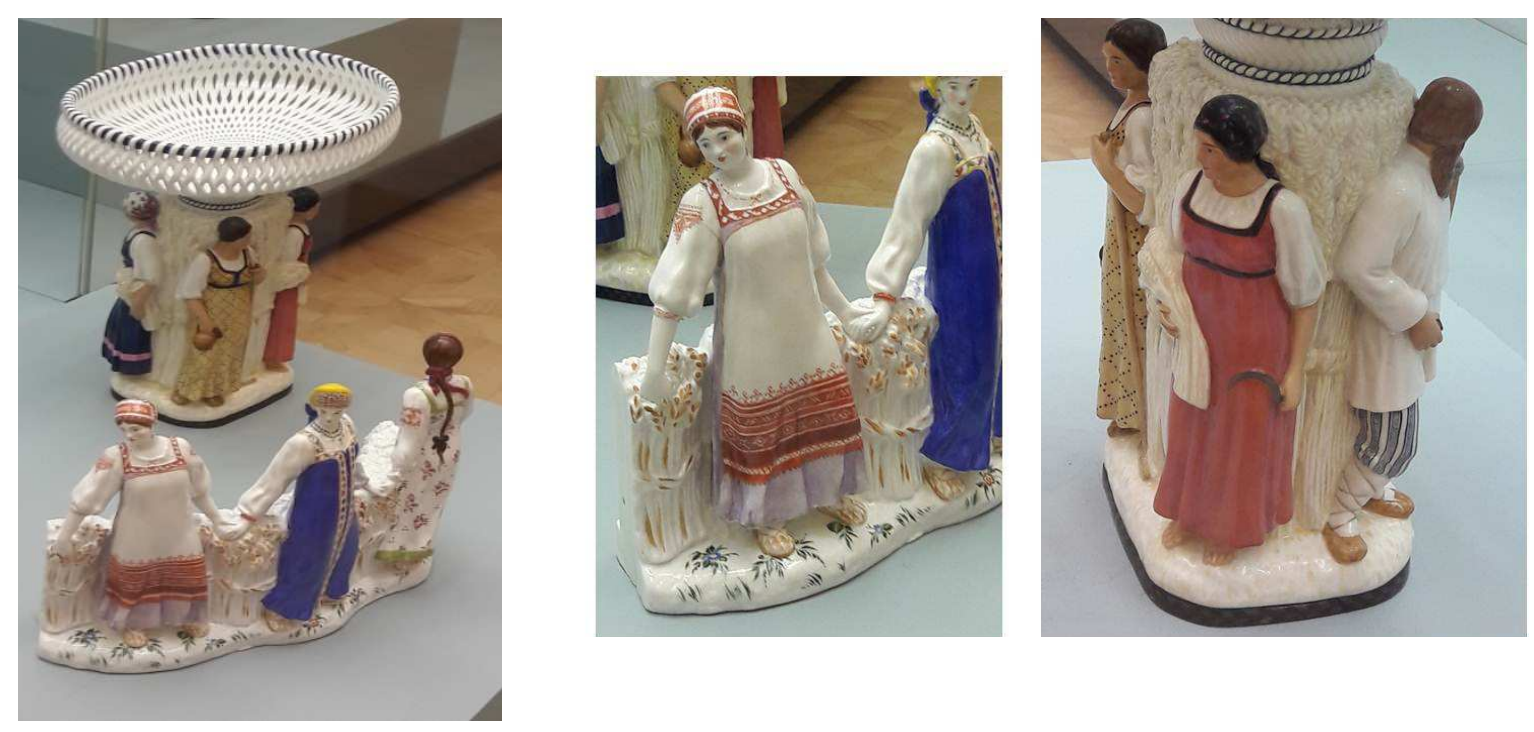

Рисунок 6 - Ваза «Жнецы» Е.Е. Лансере, Н.Я. Данько (слева), 1915 г.; фрагмент настольного украшения Императорский фарфоровый завод, Е.Е.Лансере, Н. Я. Данько (справа), 1916 г. 
Второй блок иконографии пшеницы в живописи отражает видовое разнообразие культуры по колосу. Колос пшеницы является сложным соцветием и состоит из отдельных колосков, расположенных на уступе колосового стержня. В итальянской живописи, как показал проведенный визуальный анализ, больше всего изображался пшеничный колос.

На картинах Джузепа Арчимбальдо «Четыре сезона» несколько вариантов, 1563 г; «Портрет чешского короля Рудольфа II в образе Вертемнуса», 1573 г.; Аллегория времен года,1563г. (рисунок 7-9) представлены 8 видов пшениц остистых и безостые, с коротким, плотным колосом, длинным, рыхлым колосом.
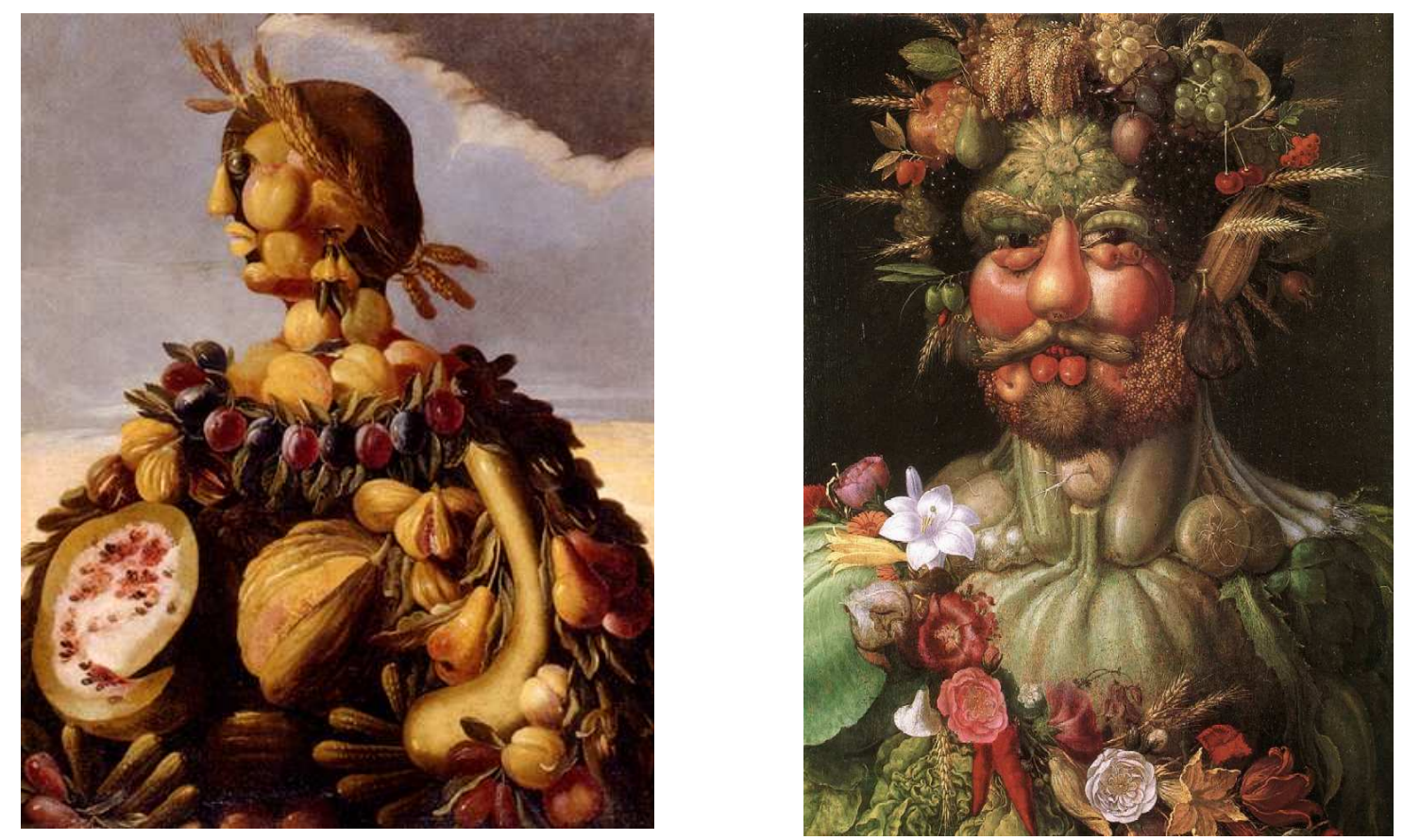

Рисунок 7 - Сезоны. Картина-4. Джузеппе Арчимбольдо, 1589 г.(слева); Портрет чешского короля Рудольфа II в образе Вертемнуса,

1573г. (справа) 


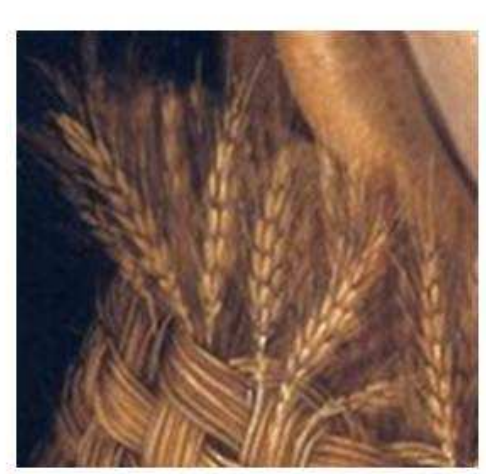

a

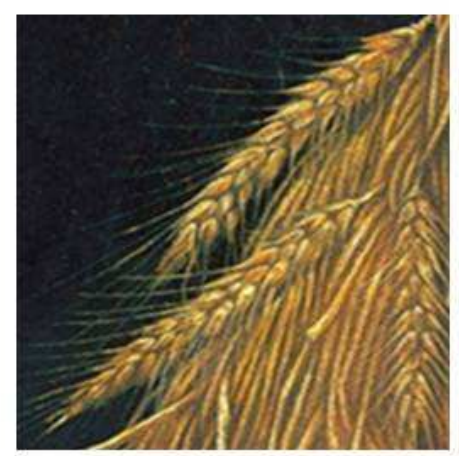

$\Gamma$

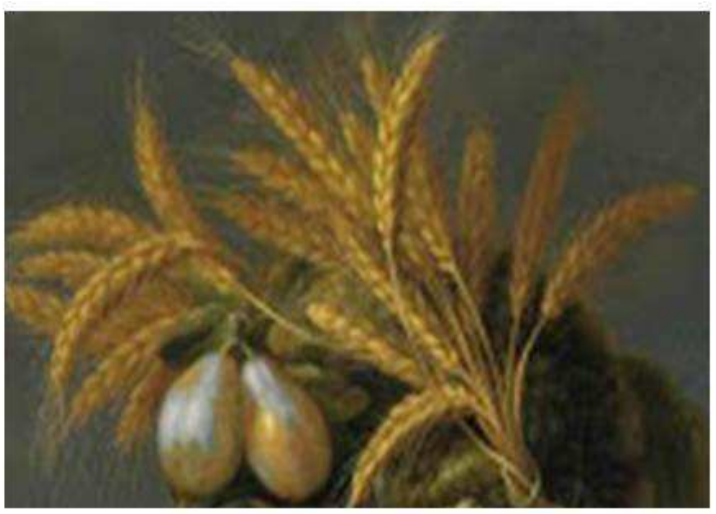

ж

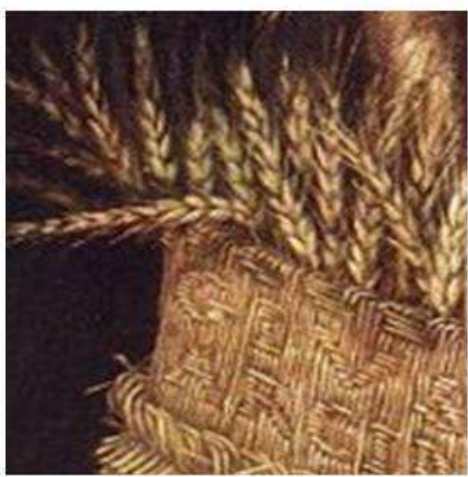

6

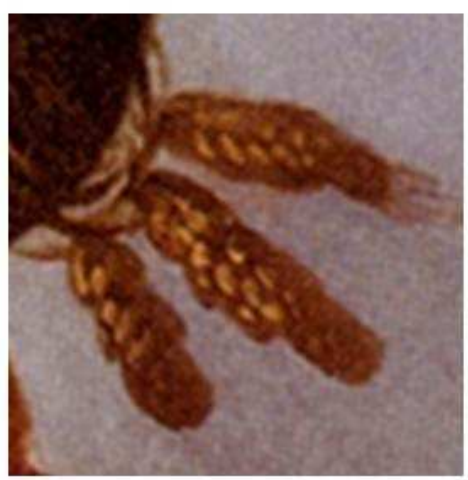

A

3
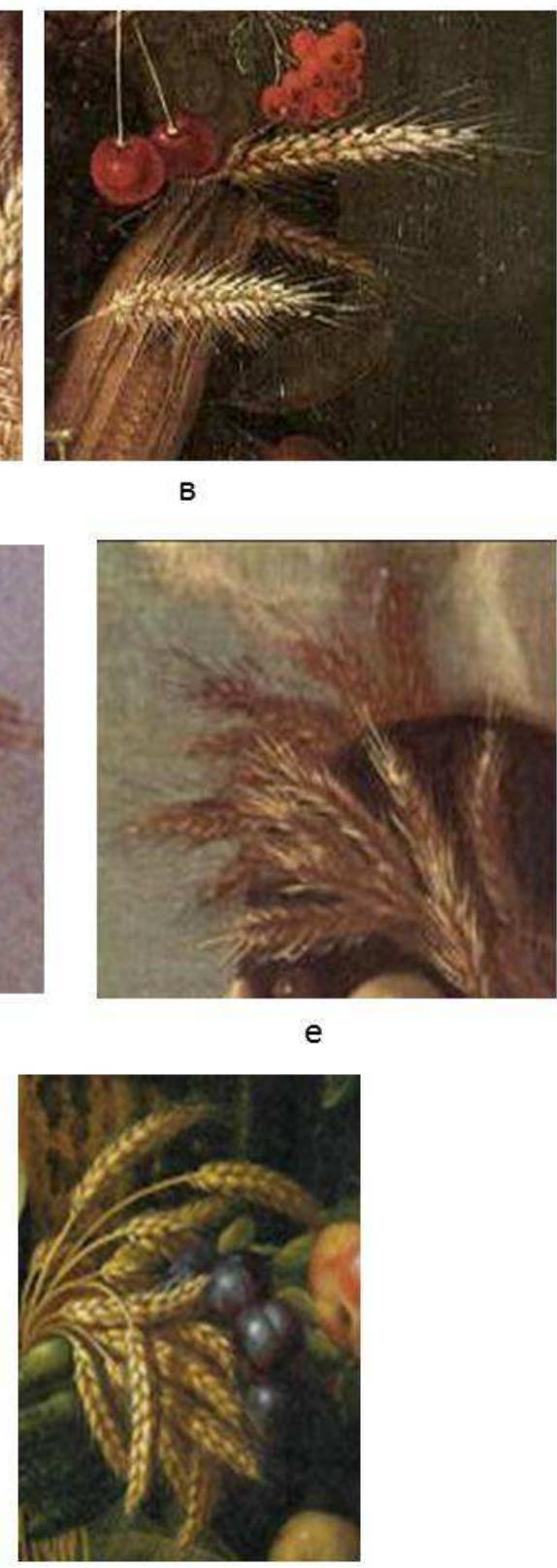

B

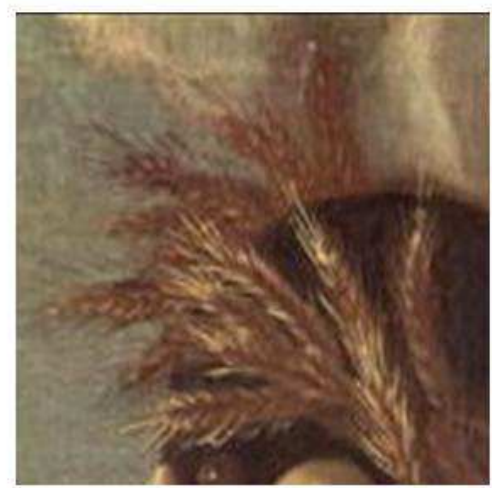

e

Рисунок 8 - Виды пшеницы в картинах Джузеппе Арчимбольдо:

Четыре сезона, Лето 2, 1563 г.(а); Лето, 1563 г.(б); Портрет чешского короля Рудольфа II в образе Вертемнуса, 1573 г. (в); Четыре сезона, 1590 г.(г); Сезоны. Картина-4. 1589 г.(д); Четыре сезона, Лето 2, 1563 г. (е); Аллегория времен года, 1563 г. $(ж, 3)$

На картине «Четыре сезона, Лето 2, 1563 г.(а); фрагмент картины рисунок 6а и «Четыре сезона, 1590 г.» фрагмент (рисунок 6г) изображена пшеница с тонкой и гибкой соломиной, которая служит сырьем для производства шляп. Как пишут Шуман и Гильг «Пшеничная солома различна по длине, достаточно питательна и идет на корм скоту в виде 
резки, одна из рановидностей, растущая на очень плохой почве в Тоскане, дает в своих тонких прочных соломинах материал для приготовления флорентийских соломенных шляп» [18].

С венком из колосьев или снопом часто изображалась богиня плодородия и урожая Церера. Именно ей обязана своим появлением прическа «а ' la Ceres» с вплетенными в волосы колосьями. Пшеница и рожь, несомненно, обладали феминным подтекстом, поэтому некоторые предметы женского быта, например, шкатульки для рукоделия, укрошались изображением венка с включением колосьев.

Колосья были неотьмлемой частью аллегории Земледелия и Хлебопашества, изображавшиеся в виде девушки, облокотившейся на плуг и держащей снопы. Они присутствуют на иконорагфическом изображении Польцы. О последней написано:

«Она увенчалось колосьями и виноградом... держит дубовую ветв, с плодами илистьями, украшенными ... все они эмблемы заключают о полезной жизни»

Большую популярность приобели «народные образы», т.е. характерные сельские сцены (изображение жатвы или крестьян с серпами на фоне колосьев». Изображение колоса в венке встречается в картине Брейгеля Яна Старшего «Церера и 4 элемента», 1604 г.; Антуан Ватто (1684-1721). Лето. 1712.

Среди форм пшеницы, изображенных на картинах итальянских художников, выделяется блок многоцветковых пшеницы. У обычных сортов в колоске пшеницы встречается от 3 до 4 или 5 цветков и зерен на XII этапе органогенеза. Многоцветковые формы отличаются от обычных тем, что в колоске может образовываться от 5 до 7 и 8 цветков. Зерно, как правило, крупное или наоборот щуплое. В агроботанической иллюстрации XVIII в. показаны эти формы (рисунок 10). Также они встречаются в живописных полотнах лоджии Рафаэля (Государственный Эрмитаж) 
колосья на рисунке 10 верхний ряд, у О.А.Кипренского « Портрет танцовщицы Телешовой»,1828 г., в натюрмортах Абрагама Миньона (1640-1679). Цветы в вазе (слева); Плоды (справа) (Государственный Эрмитаж) и на плитке печного изразца Музей Кувена, Ахен, Германия, 1787 г.(рисунки 13,15).

Согласно имеющимся образцам семян многоцветковой пшеницы, предоставленных отделом Пшениц, ФГБНУ Всероссийский институт растениеводства (ВИР) (г.Санкт-Петербург) в коллекции находятся образцы из Германии (Bergers Unbegrannter Dickkopf, разновидность milturum, 40507) который возделывался в стране до 1949 года (рисунок 15). В России выращивали многоцветковые формы в Ростовской области (Банатка, разновидность ferrugineum, 9462), Смоленской области (Сандомирка, разновидность leucoaspermum, 9787 и Костромка, разновидность milturum, 11757). Большое разнообразие многоцветковых форм выращивалось в Италии (Novaro, разновидность milturum, 42747; Domiano x Eimocco, разновидность lutescens, 44772; Fenotipo 1, разновидность milturum 44766; Fenotipo 2, разновидность Barbarossa, 44767; Lama, разновидность milturum 449550). (рисунки 9, 10). Многоцветковые пшеницы коллекции ВИР представлены и китайскими образцами. Первый образец из Шеньси, разновидность lutescens, 28569, второй из местности Сычуанеь, разновидность erythrospermum, 44001 и третий образец Nan-jing-can-lap, разновидность lutescens, 62756. На картине китайского художника Shibata Zeshin представлен колос многоцветковой пшеницы (рисунок 14). 


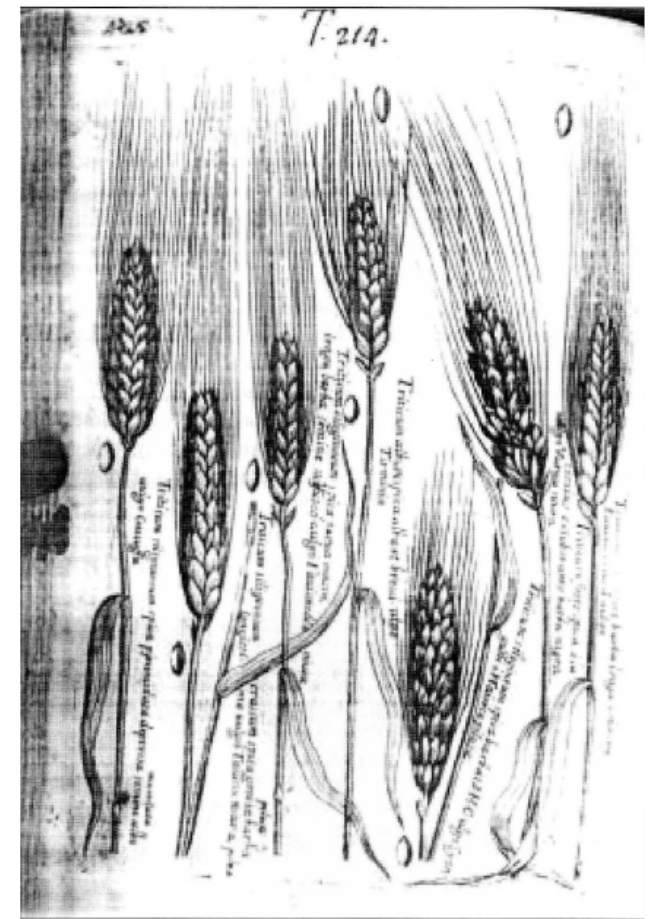

Fig. 4. Table with wheat in the Cupani's 'Panphyton' specimen kept in the for mer Jesuit Library now Biblioteca Centrale della Regione siciliana.

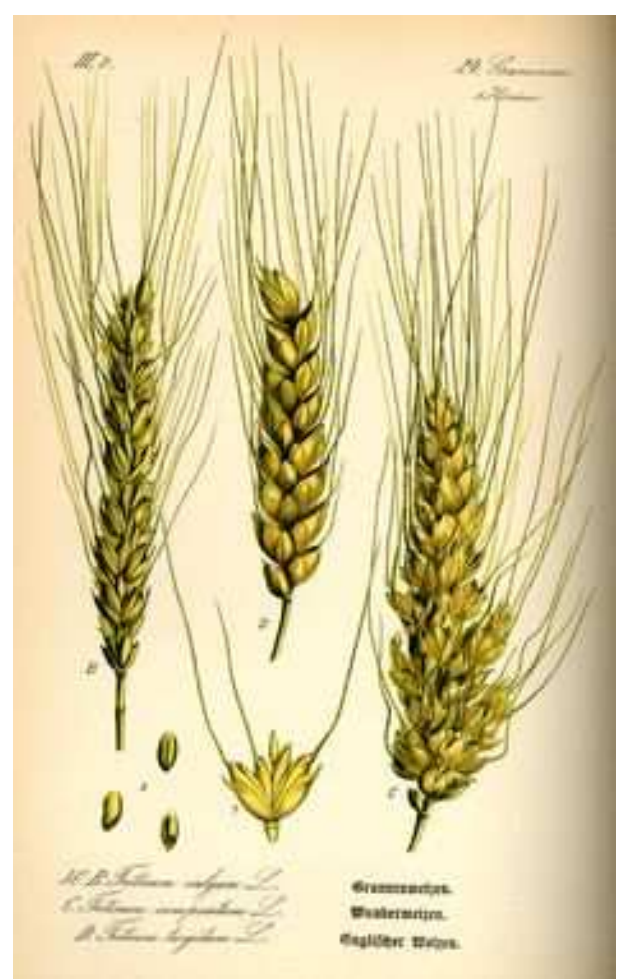

Рисунок 9 - Колосья многоцветковой пшеницы из агроботанической иллюстрации, XVIII в.
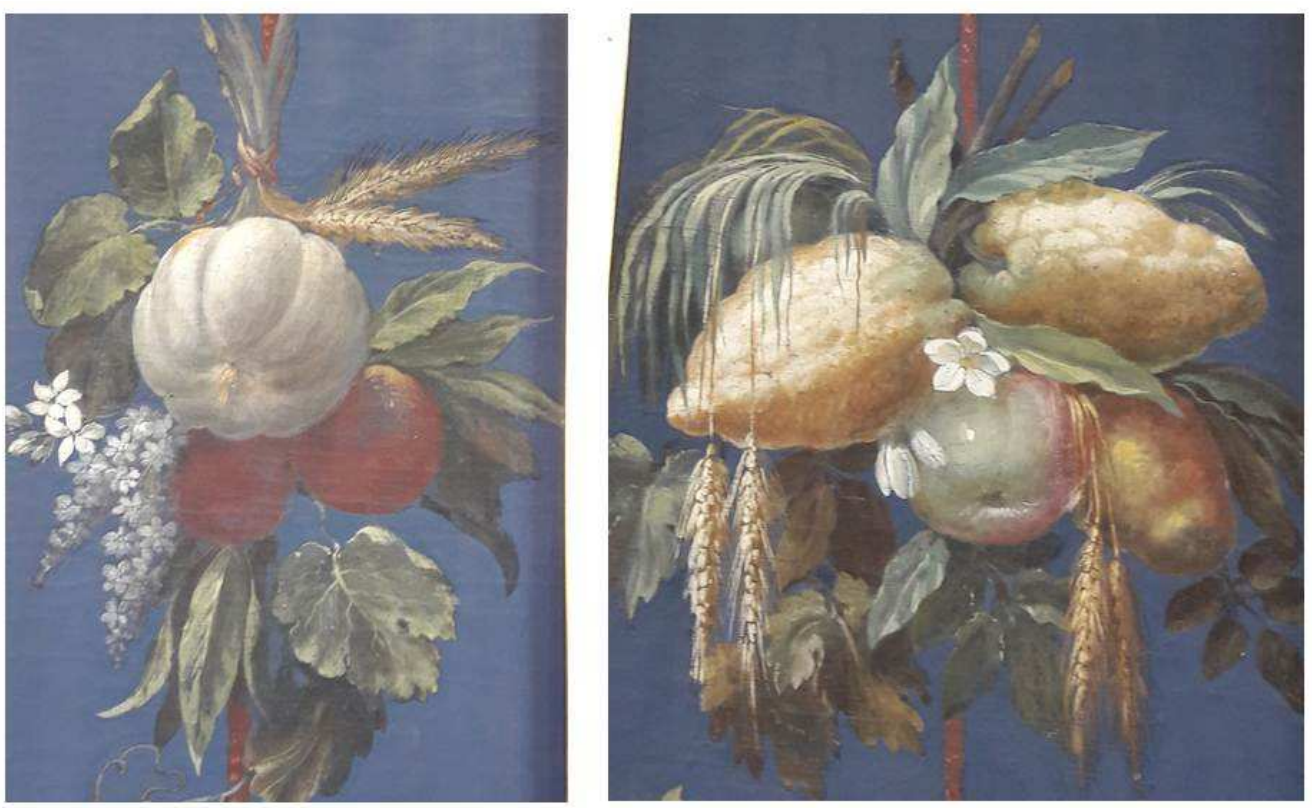

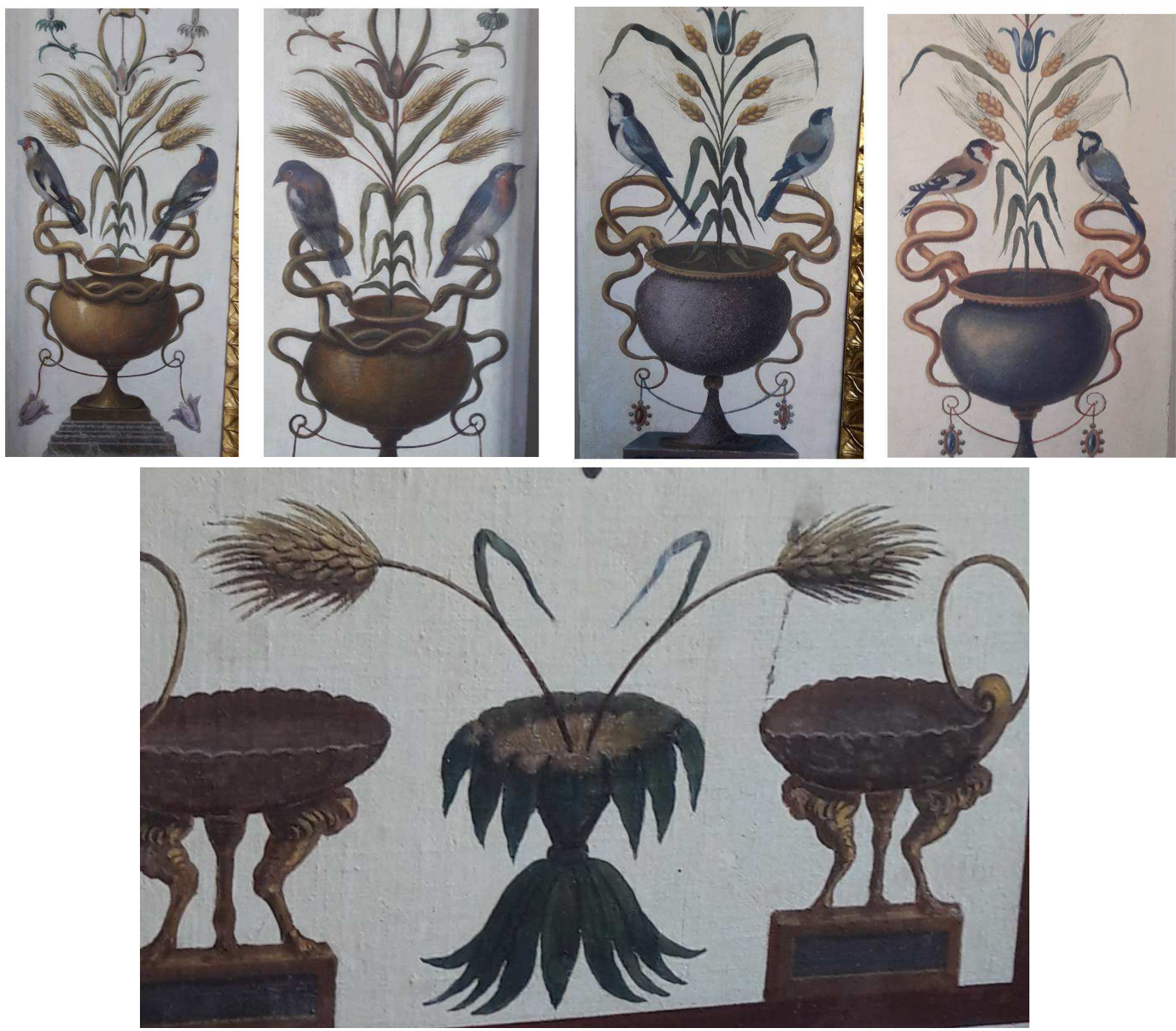

Рисунок 10 - Различные формы колосьев пшеницы, Лоджии Рафаэля, Государственный Эрмитаж, 1792 г.Санкт-Петербург
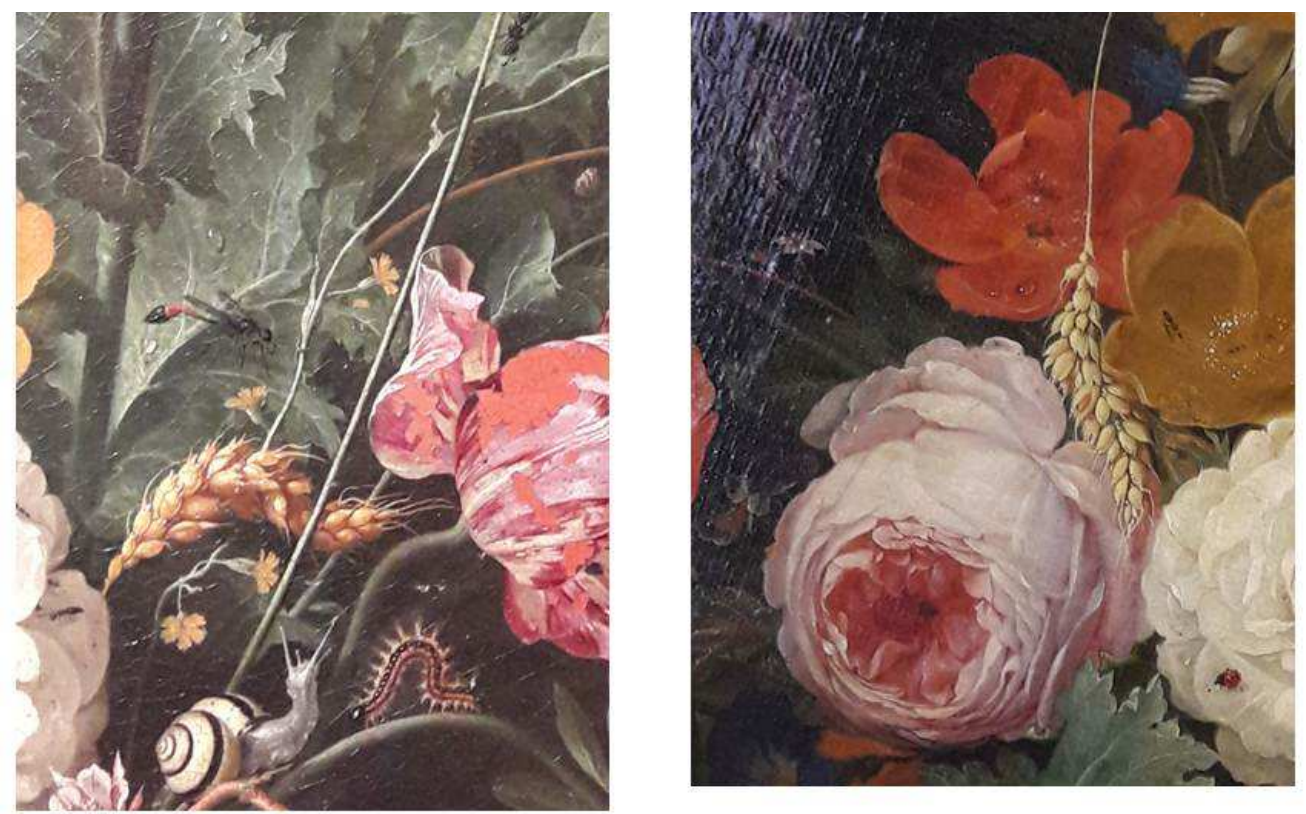
Рисунок 11 - фрагмент картин с изображением колоса пшеницы, Абрагам Миньон (1640-1679). Цветы в вазе (слева); Плоды (справа)
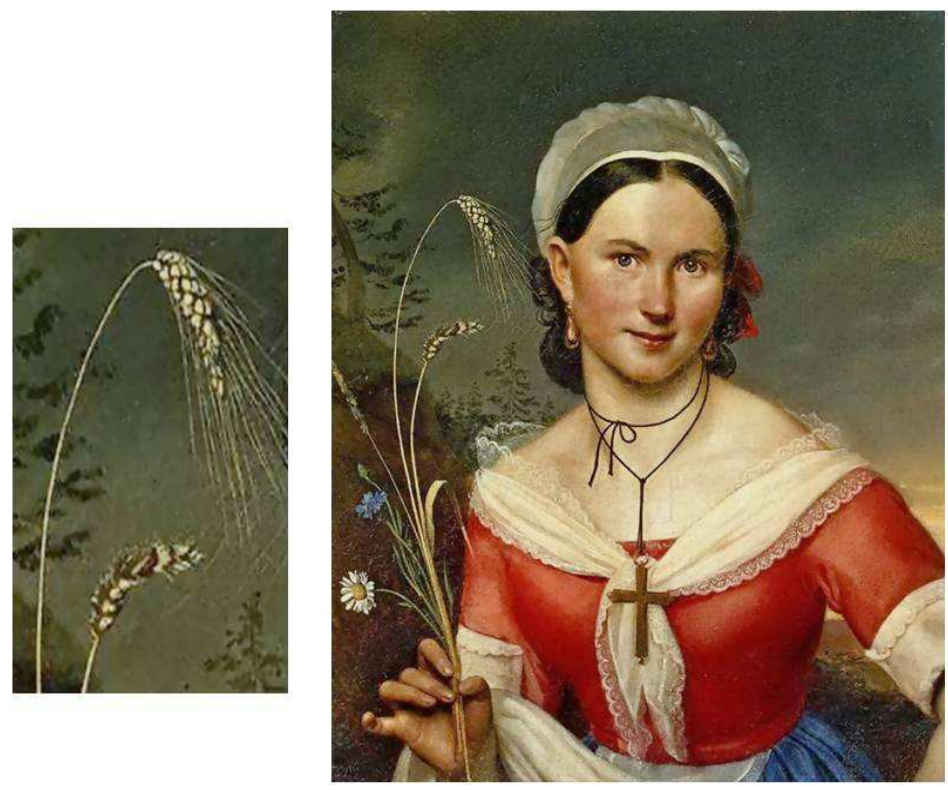

Рисунок 12 - Портрет танцовщицы Телешовой, О.А. Кипренский, 1828 г.

Возделывание пшеница в России имело взлеты и падения. В одни времена Россия кормила почти половину Европы и имеются сведения, что даже в Италии делали макаронные изделия из нашей твердой пшеницы, в другие времена - наша страна становилась импортером и полностью зависела от поставок зерна. Большое значение для распространения этой культуры на территории России имел манифест Екатерины II, разрешающий иностранцам селиться в России. Результатом этого документа стало то, что в страну с 1763 по 1766 гг. приехало более 30000 человек, большая часть которых, около $60 \%$ поселилась в Поволжье, в районе Саратова, образовав несколько десятков колоний. Колонисты помимо введения новой культуры земледелия, в значительной степени расширили перечень возделываемых сельскохозяйственных растений. Выращивали пшеницу, ячмень, картофель, табак, овес, тыквенные, увеличили посевы льна и конопли [7].

В исторических документах упоминается такая информация «... в России крестьяне стали развивать производство зерна, используя 
профессиональные навыки и технологии переселенцев. Как писали в «Трудах Вольно-Экономического Общества» колонисты посредством почтовой переписки получили семена из различных стран и местностей. Во второй половине XVIII в России культивировали большое разнообразие злаков из разных стран: Италии, Германии, Франции, Персии, Египта и др.

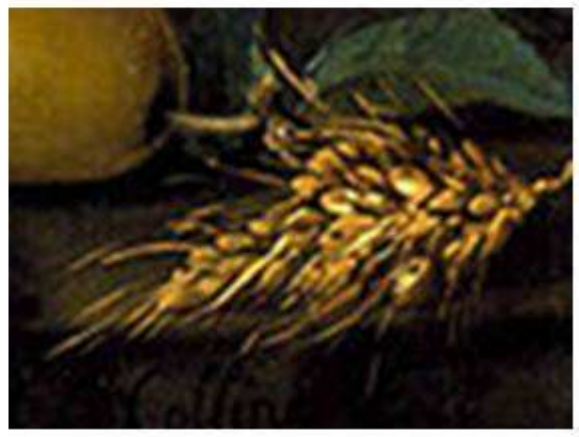

a

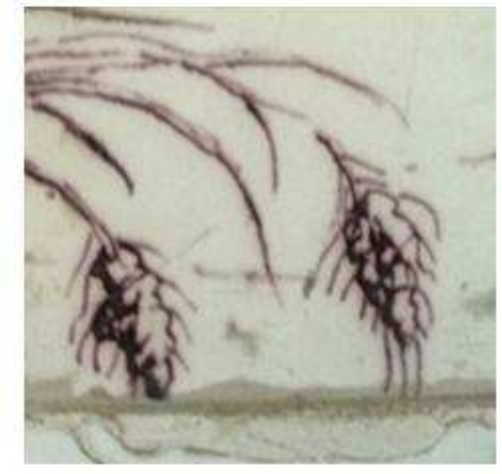

6

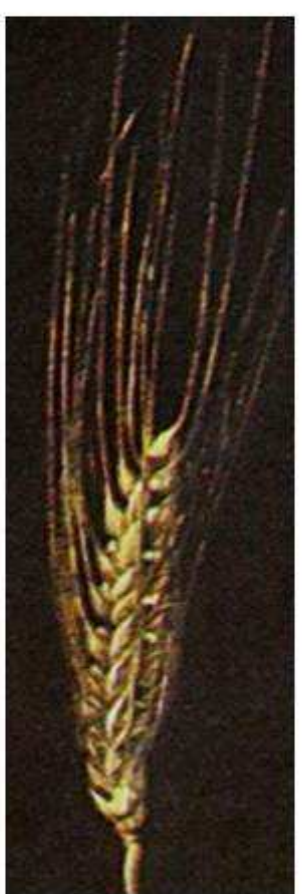

B

Рисунок 13- Ветвистые пшеницы: персики и виноград, Чарлз Коллинс, 1734 г.; изображение многоцветковой пшеницы на изразцовой плитке, Музей Кувена, Ахен, Германия, 1787 г.(б); остистая пшеницы, Колос пшеницы. Сальвадор Дали. 1947 г.(в)

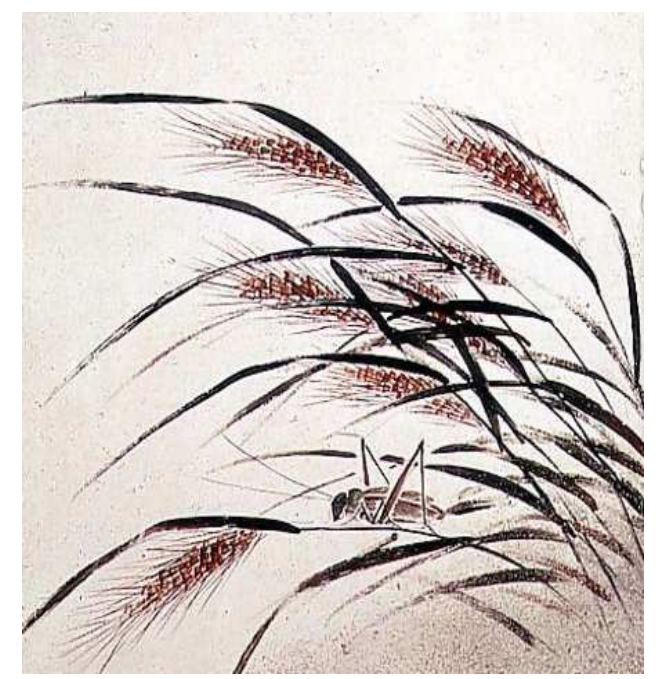

Рисунок 14 - Колос многоцветковой пшеницы. Кузнечик и пшеница. Шибата Зекхин, 1908 г. Китай. 


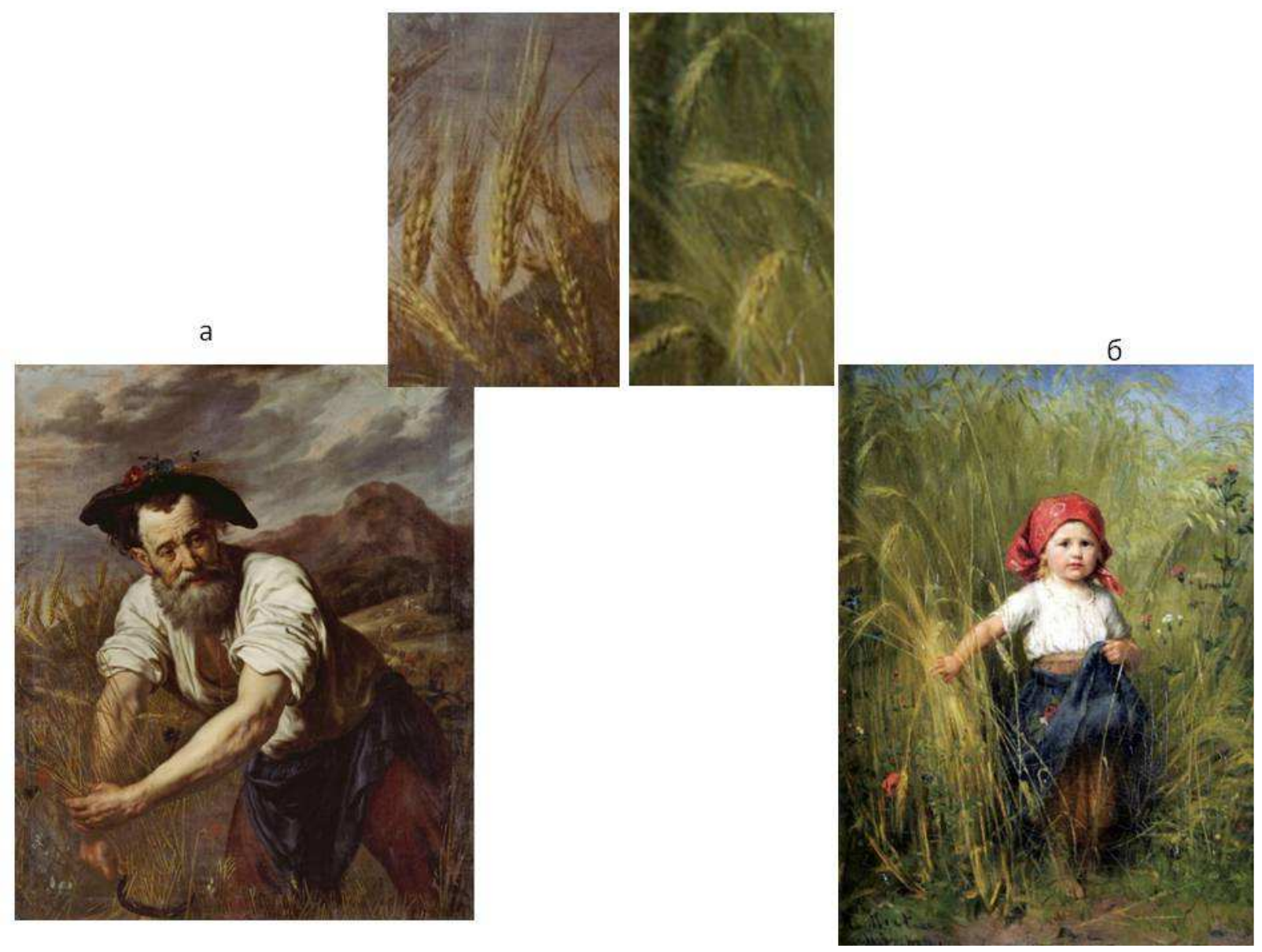

Рисунки 15 - Формы пшеницы изображенные в картинах немецких художников. «Двенадцать месяцев» Иоахим фон Зандрарт Старший 1645 (а); Генрих Хирт, (1841 - 1902 гг.) Девочка в пшеничном поле (б)

Колос и само растение пшеницы изображали многие художники: Никола Пуссен. «Времена года». Лето. Руфь 1660-1664 гг.; Ян Давидс де Хем. «Плоды и ваза с цветами», 1670 г.; «Большой натюрморт с птичьим гнездом», 1670 г.; Мария ван Остервейк (1630-1693). «Ваза с тюльпанами, розами и другими цветами и насекомыми»; «Натюрморт с цветами, подсолнухом и раковинами»; Николас Берхем, 1620, Харлем, 1683 г., «Аллегория осени; Жан-Батист Удри «Собака на стойке перед куропаткой»; 1686 г.,Винсент Ван Гог «Стог пшеницы», 1885 г.; «Пшеничное поле,1890 г.; Джон Оттис Адамс. «Отдых», 1886 г.; И.Ф.Хруцкий «Цветы и фрукты», 1839 г.; Антуан Ватто «Лето», 1712.; 
Генрих Хирт, (1841 - 1902 гг.) «Уборка пшеницы»; Абрахам Миньон «Корзина с фруктами», 1670 г.; «Фрукты», 1671 г.

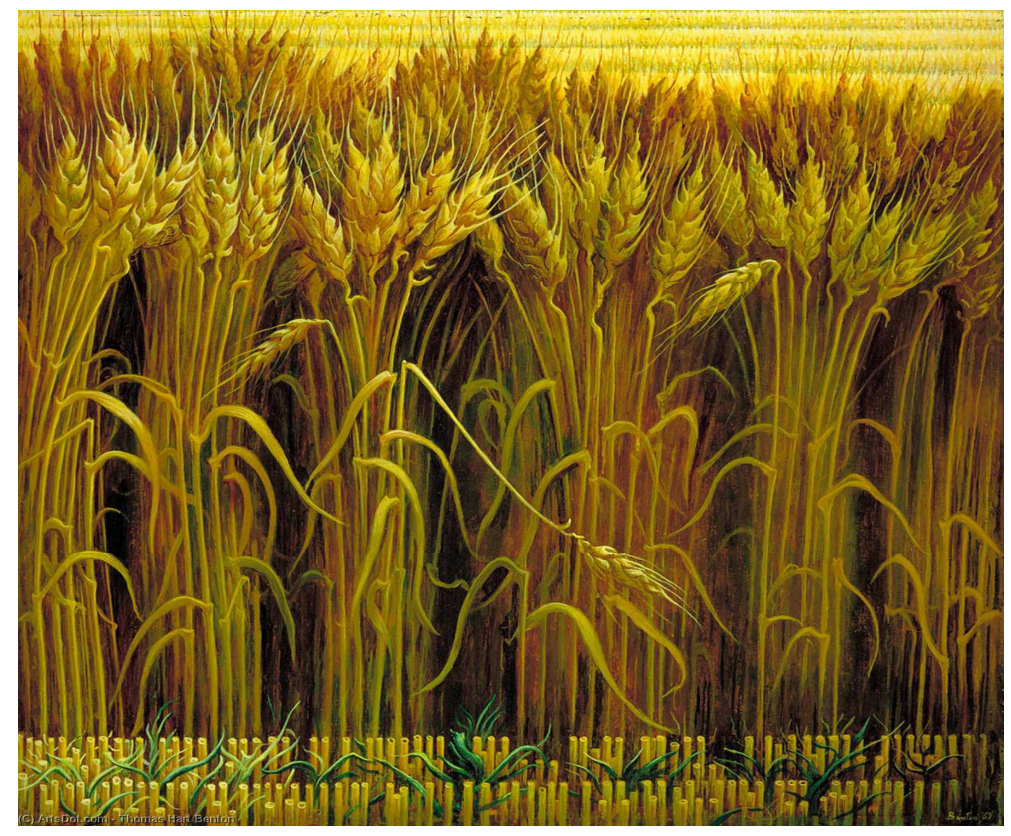

Рисунок 16 - Поле пшеницы, Томас Харт Бертон (1889-

1975, США

Третий блок образов представляют короткостебельные формы. На картине Томаса Харта Бертона изображены короткостебельные пшеницы с небольшим, хорошо озерненным плотным колосом. На переднем плане картины видны срезы, обкосы поля, которые делают перед уборкой хлебов. По срезу можно видеть, что соломина прочная, уплотненная по стенкам. Известно, что самая сильная склонность к полеганию у пшеницы наблюдается при высоте растений свыше 120 см. Полегание у пшеницы ограничивает потенциал продуктивности, что приводит к заметному изменению обменных процессов у растений, к усиленному развитию грибковых заболеваний, снижению качества зерна и затруднению уборки урожая. В некоторые годы потери урожая зерна пшеницы от полегания составляют от 25 до 90\%. На сегодняшний день одним из основных методов борьбы с полеганием является выведение низкорослых неполегающих сортов (рисунок 16). На сегодняшний день продолжаются работы по созданию короткостебельных форм пшеницы с повышенной 
прочностью соломины, слабо меняющие высоту растений в контрастные по погодным условиям годы [5,9].

Изображение пшеничного растения на монетах дает нам информацию о странах, где возделывается эта культура (рисунок 17).
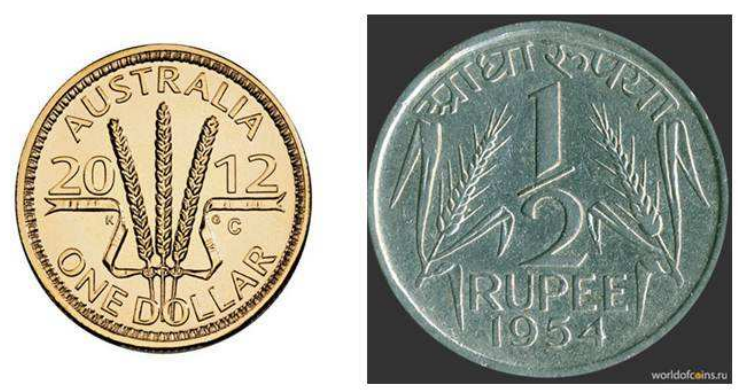

Рисунок 17 -Монеты разных стран с видами колосьев пшеницы
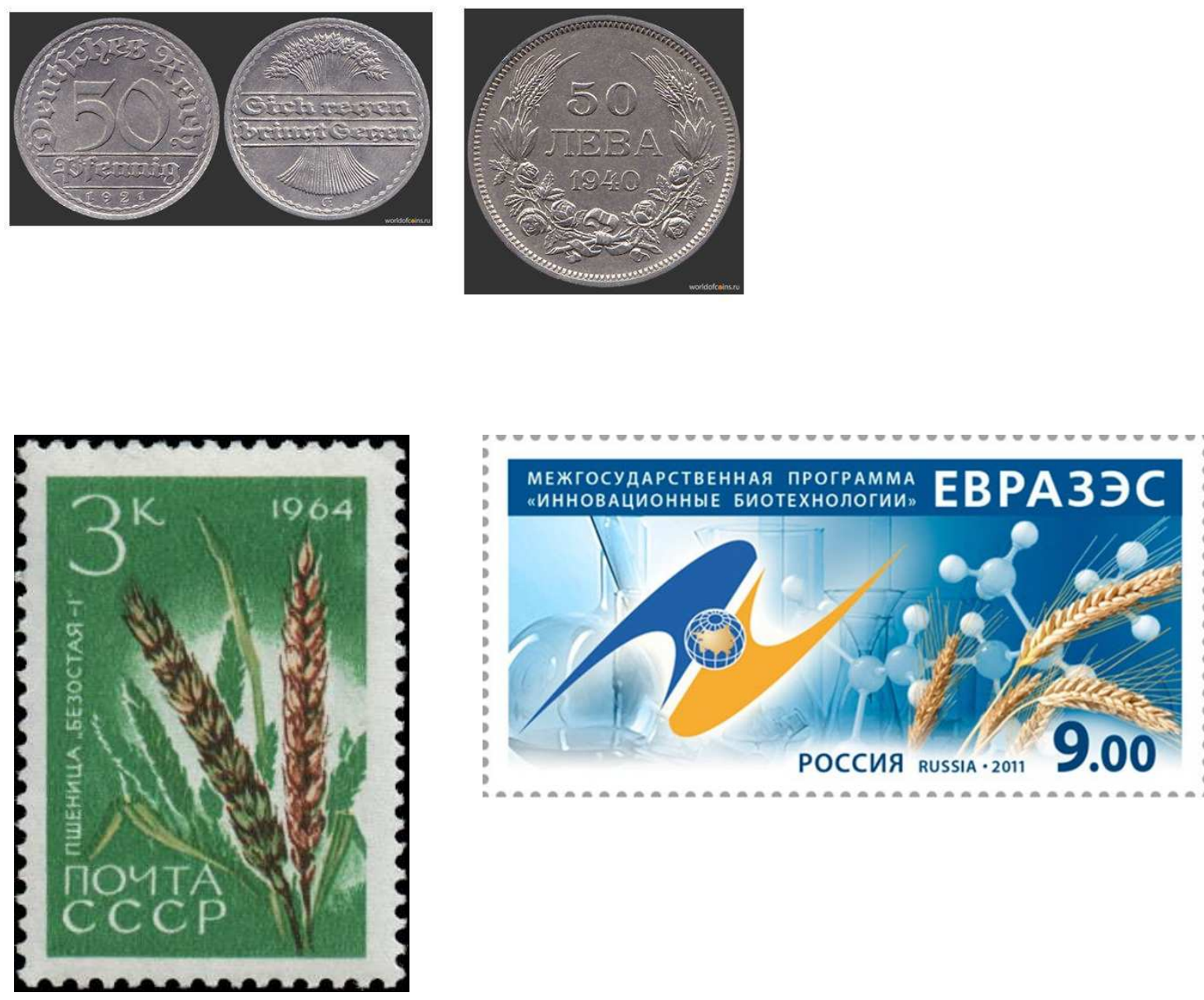

Рисунок 18 - Марка с изображением колоса сорта пшеницы «Безостая 1», 1964 г. (слева); колос пшеницы, марка РФ, 2011 г.

Марки являются отражением многих аспектов развития каждой страны, можно сказать они отражают эпоху. 
В нашей стране в 1964 году была выпущена уникальная серия из 7 марок с изображением основных полевых культур (рисунок 19). В серию вошел сорт озимой мягкой пшеницы Безостая 1, выведенный в Краснодарском научно-исследовательском институте сельского хозяйства путем индивидуального отбора. Авторы сорта - П.П. Лукьяненко, Н.Д. Тарасенко. Сорт вошел в историю отечественной и мировой селекции тем, что отличался высокой пластичностью и повышенной продуктивностью, проявившейся при посевах в различных почвенно-климатических зонах страны. В 1974 г. сорт Безостая 1 в нашей стране занимал площадь 4 млн. 887,7 тыс. га и в зарубежных социалистических странах - свыше 4 млн. га, был районирован в 45 областях, краях и республиках.

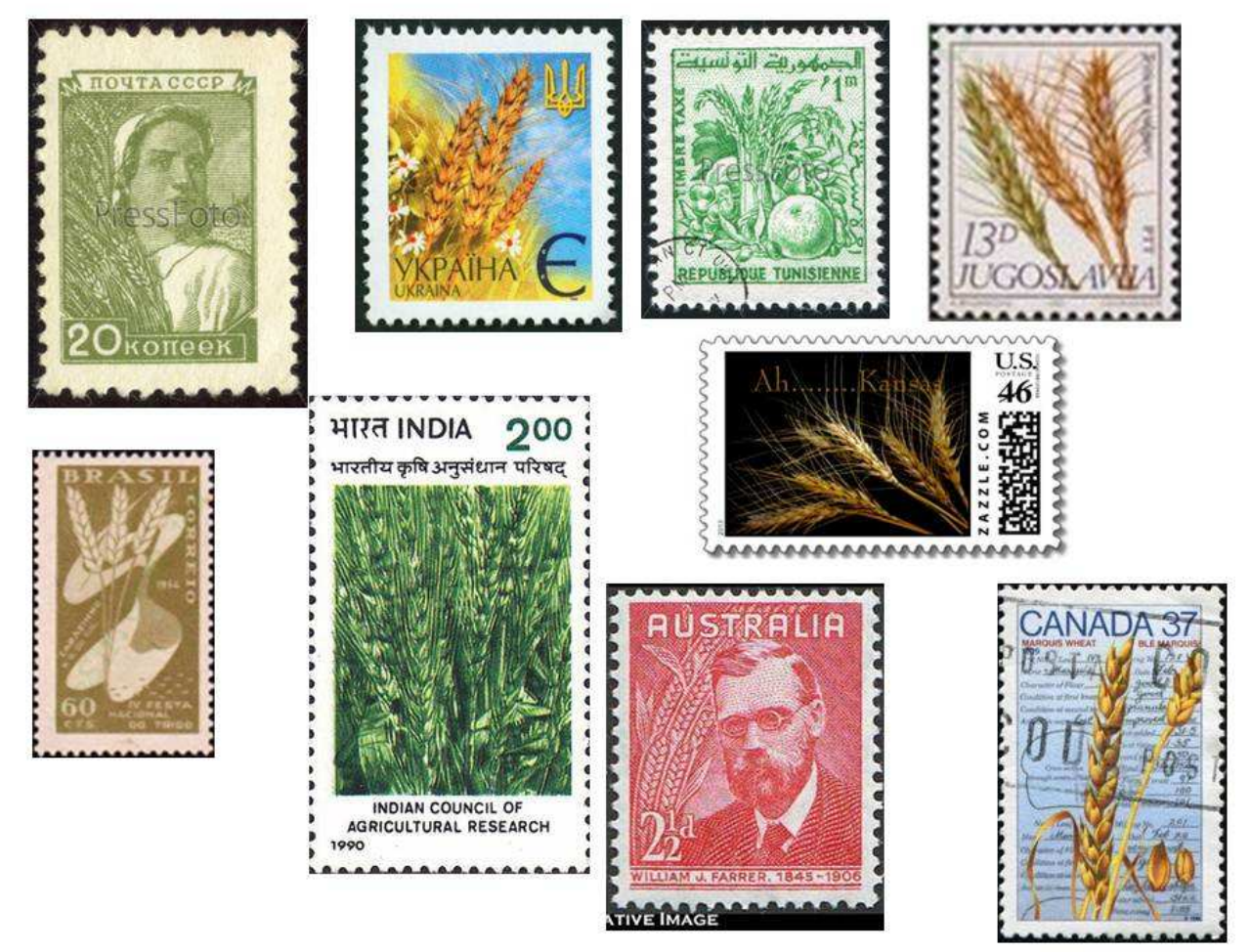

Рисунок 19 - Марки с изображением колоса пшеницы в странах, где она возделывается: Россия, Украина, Египет, Югославия, Бразилия, Индия Австралия, Канада

Таким образом, проведенный визуальный анализ образов пшеницы в произведениях искусства методом скетчей позволил выявить видовое разнообразие культуры по колосу, увидеть стародавние формы, которые 
возделывались в мире до «зеленой революции». Можно выделить основные селекционные цели по культуре: способность пшеничного растения за счет признаков и свойств противостоять неблагоприятным условия во время вегетации, не снижая хозяйственно-ценный урожай, устойчивость соломины и короткостебельность, устойчивость против фузариоза колоса, селекция на устойчивость к мучнистой росе и бурой ржавчине, патогенным корневым гнилям, вирусным болезням, расширение генофонда культуры за счет интрогрессии генов диких сородичей. И возможно отдельные признаки можно будет найти в изображении пшеницы в картинах современных художников в недалеком будущем.

Исследование выполнено при финансовой поддержске РФФИ и Правительства Краснодарского края в рамках научного проекта №17-13 -23001 "Северный Кавказ: традиции и современность".

\section{Литература}

1. Беккер Х. Селекция растений / Х. Беккер. - М. : Товарищество научных изданий КМК, 2015. - 425 с.

2. Гончаров Н.П. Доместикация пшениц / Н.П.Гончаров, И.Д. Сормачева //Природа. - 2014. -№2. - С.45-543

3. Коваль С.Ф. Пахари и скотоводы /С.Ф. Коваль.- Новосибирск: Изд-во СО PAH.- 2009. - 468 c.

4. Малюга Н.Г. Перспективы растениеводства в XXI веке / Н.Г.Малюга, Л.В.Цаценеко // Аграрная наука. -1998. № 4. - С.14-15.

5. Митрофанова О. П. Генетические ресурсы пшеницы в России: состояние и предселекционное изучение / О. П. Митрофанова // Вавиловский журнал генетики и селекции.- 2012. - Том 16. - №1. - С. 10-20.

6. Митрофанова О. П. Структура генетических взаимосвязей между местными сортами гексаплоидных пшениц по данным RAPD-, AFLP- и SSR-анализов / О. П. Митрофанова, П. П. Стрельченко, А. В. Конарев // Аграрная Россия.- 2005. - № 6. - С. $10-19$.

7. Носатовский А. И. Пшеница. Биология. М.: Колос, 1965. - 586 с.

8. Павлов И.Н. Преподавание лесохозяйственных и биологических дисциплин с использованием произведений великих художников/И.Н., Павлов, О.А.Баранова // Высшее образование сегодня. - 2009. -№2. -С.63-66.

9. Пшеница и ее улучшение [Текст] / Пер. с англ. Н. А. Емельяновой и Н. М. Резниченко ; Под ред. д-ра с.-х. наук М. М. Якубцинера [и др.] ; [Предисл. заслуж. деят. науки, д-ра биол. наук, проф. Н. Козьминой и др.]. - Москва : Колос, 1970. - 519 с. 
10. Степанова Т.М. Иконика: Проектная концепция новой, интегральной учебной дисциплины / Т.М. Степанова, А.В.Степанов //Альманах современной науки и образования. - 2013.- № 12 (79). -С.160-164.

11. Цаценко Л.В. Изображение растений, как материал для анализа в генетике и селекции. Ламберт Академик Пресс.Германия.-2014.- 85с.

12. Цаценко Л.В. Иконография пшеницы /Л.В. Цаценко, С.С.Кошкин. Свидетельство регистрации база данных № 2013620717 от 19.06.2013, За-явка № 2013620326 от 09.04.2013

13. Цаценко Л.В. Роль научной иллюстрации в истории биологии / Л.В. Цаценко // Политематический сетевой электронный научный журнал Кубанского государственного аграрного университета (Научный журнал КубГАУ) [Электронный peсурс]. - Краснодар: КубГАУ, 2012. - №10(084). С. 358 - 366. - IDA [article ID]: 0841210029. - Режим доступа: http://ej.kubagro.ru/2012/10/pdf/29.pdf, 0,562 у.п.л.

14. Цаценко Л.В. Интерпретация художественного произведения как технология познавательного процесса по предметной области в курсе «История и методология научной агрономии» / Л.В. Цаценко // Политематический сетевой электронный научный журнал Кубанского государственного аграрного университета (Научный журнал КубГАУ) [Электронный ресурс]. - Краснодар: КубГАУ, 2015. - №05(109). С. 1154 - 1168. - IDA [article ID]: 1091505080. - Режим доступа: http://ej.kubagro.ru/2015/05/pdf/80.pdf, 0,938 у.п.л.

15. Цаценко Л.В. Метод скетчей в археогенетике и селекции сельскохозяйственных растений / Л.В. Цаценко // Политематический сетевой электронный научный журнал Кубанского государственного аграрного университета (Научный журнал КубГАУ) [Электронный ресурс]. - Краснодар: КубГАУ, 2015. №02(106). С. 1083 - 1097. - IDA [article ID]: 1061502071. - Режим доступа: http://ej.kubagro.ru/2015/02/pdf/71.pdf, 0,938 у.п.л.

16. Цаценко Л.В. Советский фарфор как ресурс информации в курсе «История и методология научной агрономии» / Л.В. Цаценко, Н.А. Цаценко // Политематический сетевой электронный научный журнал Кубанского государственного аграрного университета (Научный журнал КубГАУ) [Электронный ресурс]. - Краснодар: КубГАУ, 2015. - №05(109). С. 500 - 511. - IDA [article ID]: 1091505029. - Режим доступа: http://ej.kubagro.ru/2015/05/pdf/29.pdf, 0,75 у.п.л.

17. Цаценко Л.В. Почтовая марка как ресурс информации по истории агрономии / Л.В. Цаценко, А.А. Магомедтагиров // Политематический сетевой электронный научный журнал Кубанского государственного аграрного университета (Научный журнал КубГАУ) [Электронный ресурс]. - Краснодар: КубГАУ, 2017. - №01(125). С. 66 - 84. - IDA [article ID]: 1251701002. - Режим доступа: http://ej.kubagro.ru/2017/01/pdf/02.pdf, 1,188 у.п.л.

18. Шуман К., Гильг Э. Мир растений. Перевод с немецкого А.А.Рихтера. СПетербург, 1906.-739c.

19. Janick J. Plant Iconography and art: source of information on horticultural technology / J.Janick // Bulletin UASVM Horticulture.2010 N 67(1)- P. 11-23.

20. Janick J. The first images of maize in Europe / J. Janick, G.Caneva // Maydica. 2005. N 50. - P. 71-80.

\section{References}

1.Bekker H. Selekcija rastenij / H. Bekker. - M. : Tovarishhestvo nauchnyh izdanij KMK, 2015. - $425 \mathrm{~s}$.

2.Goncharov N.P. Domestikacija pshenic / N.P.Goncharov, I.D. Sormacheva //Priroda. - 2014. -№2. - S.45-543 
3.Koval' S.F. Pahari i skotovody /S.F. Koval'.- Novosibirsk: Izd-vo SO RAN.- 2009. $468 \mathrm{~s}$.

4.Maljuga N.G. Perspektivy rastenievodstva v XXI veke / N.G.Maljuga, L.V.Caceneko // Agrarnaja nauka. -1998. № 4. - S.14-15.

5.Mitrofanova O. P. Geneticheskie resursy pshenicy v Rossii: sostojanie i predselekcionnoe izuchenie / O. P. Mitrofanova // Vavilovskij zhurnal genetiki i selekcii.2012. - Tom 16. - №1. - S. 10-20.

6.Mitrofanova O. P. Struktura geneticheskih vzaimosvjazej mezhdu mestnymi sortami geksaploidnyh pshenic po dannym RAPD-, AFLP- i SSR-analizov / O. P. Mitrofanova, P. P. Strel'chenko, A. V. Konarev // Agrarnaja Rossija.- 2005. - № 6. - S. 10-19.

7.Nosatovskij A. I. Pshenica. Biologija. M.: Kolos, 1965. - 586 s.

8.Pavlov I.N. Prepodavanie lesohozjajstvennyh i biologicheskih disciplin $\mathrm{s}$ ispol'zovaniem proizvedenij velikih hudozhnikov/I.N., Pavlov, O.A.Baranova // Vysshee obrazovanie segodnja. - 2009. -№2. -S.63-66.

9.Pshenica i ee uluchshenie [Tekst] / Per. s angl. N. A. Emel'janovoj i N. M. Reznichenko ; Pod red. d-ra s.-h. nauk M. M. Jakubcinera [i dr.] ; [Predisl. zasluzh. dejat. nauki, d-ra biol. nauk, prof. N. Koz'minoj i dr.]. - Moskva : Kolos, 1970. - 519 s.

10. Stepanova T.M. Ikonika: Proektnaja koncepcija novoj, integral'noj uchebnoj discipliny / T.M. Stepanova, A.V.Stepanov //Al'manah sovremennoj nauki i obrazovanija. 2013.- № 12 (79). -S.160-164.

11.Tsatsenko L.V. Izobrazhenie rastenij, kak material dlja analiza v genetike i selekcii. Lambert Akademik Press.Germanija.-2014.- 85c.

12. Tsatsenko L.V. Ikonografija pshenicy /L.V. Tsatsenko, S.S.Koshkin. Svidetel'stvo registracii baza dannyh № 2013620717 ot 19.06.2013, Zajavka № 2013620326 ot 09.04.2013

13. Tsatsenko L.V. Rol' nauchnoj illjustracii $\mathrm{v}$ istorii biologii / L.V. Tsatsenko // Politematicheskij setevoj jelektronnyj nauchnyj zhurnal Kubanskogo gosudarstvennogo agrarnogo universiteta (Nauchnyj zhurnal KubGAU) [Jelektronnyj resurs]. - Krasnodar: KubGAU, 2012. - №10(084). S. 358 - 366. - IDA [article ID]: 0841210029. - Rezhim dostupa: http://ej.kubagro.ru/2012/10/pdf/29.pdf, 0,562 u.p.1.

14. Tsatsenko L.V. Interpretacija hudozhestvennogo proizvedenija kak tehnologija poznavatel'nogo processa po predmetnoj oblasti v kurse «Istorija i metodologija nauchnoj agronomii» / L.V. Tsatsenko // Politematicheskij setevoj jelektronnyj nauchnyj zhurnal Kubanskogo gosudarstvennogo agrarnogo universiteta (Nauchnyj zhurnal KubGAU) [Jelektronnyj resurs]. - Krasnodar: KubGAU, 2015. - №05(109). S. 1154 - 1168. - IDA [article ID]: 1091505080. - Rezhim dostupa: http://ej.kubagro.ru/2015/05/pdf/80.pdf, 0,938 u.p.l.

15. Tsatsenko L.V. Metod sketchej v arheogenetike i selekcii sel'skohozjajstvennyh rastenij / L.V. Tsatsenko // Politematicheskij setevoj jelektronnyj nauchnyj zhurnal Kubanskogo gosudarstvennogo agrarnogo universiteta (Nauchnyj zhurnal KubGAU) [Jelektronnyj resurs]. - Krasnodar: KubGAU, 2015. - №02(106). S. 1083 - 1097. - IDA [article ID]: 1061502071. - Rezhim dostupa: http://ej.kubagro.ru/2015/02/pdf/71.pdf, 0,938 u.p.l.

16. Tsatsenko L.V. Sovetskij farfor kak resurs informacii v kurse «Istorija i metodologija nauchnoj agronomii»/ L.V. Tsatsenko, N.A. Tsatsenko // Politematicheskij setevoj jelektronnyj nauchnyj zhurnal Kubanskogo gosudarstvennogo agrarnogo universiteta (Nauchnyj zhurnal KubGAU) [Jelektronnyj resurs]. - Krasnodar: KubGAU, 2015. №05(109). S. 500 - 511. - IDA [article ID]: 1091505029. - Rezhim dostupa: http://ej.kubagro.ru/2015/05/pdf/29.pdf, 0,75 u.p.1.

17. Tsatsenko L.V. Pochtovaja marka kak resurs informacii po istorii agronomii / L.V. Tsatsenko, A.A. Magomedtagirov // Politematicheskij setevoj jelektronnyj nauchnyj zhurnal 
Kubanskogo gosudarstvennogo agrarnogo universiteta (Nauchnyj zhurnal KubGAU) [Jelektronnyj resurs]. - Krasnodar: KubGAU, 2017. - №01(125). S. 66 - 84. - IDA [article ID]: 1251701002. - Rezhim dostupa: http://ej.kubagro.ru/2017/01/pdf/02.pdf, 1,188 u.p.l.

18.Shuman K., Gil'g Je. Mir rastenij. Perevod s nemeckogo A.A.Rihtera. S-Peterburg, 1906.-739s.

19.Janick J. Plant Iconography and art: source of information on horticultural technology / J.Janick // Bulletin UASVM Horticulture.2010 N 67(1)- P. 11-23.

20. Janick J. The first images of maize in Europe / J. Janick, G.Caneva // Maydica. 2005. N 50. - P. 71-80. 